\title{
Polychlorinated Biphenyl 153 in Lipid Medium Modulates Differentiation of Human Adipocytes
}

\author{
D. MULLEROVA ${ }^{1}$, M. PESTA ${ }^{2}$, J. DVORAKOVA ${ }^{1}$, M. CEDIKOVA ${ }^{3}$, V. KULDA $^{4}$, \\ P. DVORAK ${ }^{2}$, V. BOUCHALOVÁ ${ }^{1}$, M. KRALICKOVA ${ }^{5,6}$, V. BABUSKA ${ }^{4}$, J. KUNCOVA $^{3,6}$, \\ J. LANGMAJEROVA ${ }^{1}$, L. MULLER ${ }^{7}$
}

${ }^{1}$ Department of Public Health and Preventive Medicine, Faculty of Medicine in Pilsen, Charles University, Pilsen, Czech Republic, ${ }^{2}$ Department of Biology, Faculty of Medicine in Pilsen, Charles University, Pilsen, Czech Republic, ${ }^{3}$ Department of Physiology, Faculty of Medicine in Pilsen, Charles University, Pilsen, Czech Republic, ${ }^{4}$ Department of Medical Chemistry and Biochemistry, Faculty of Medicine in Pilsen, Charles University, Pilsen, Czech Republic, ${ }^{5}$ Department of Histology, Faculty of Medicine in Pilsen, Charles University, Pilsen, Czech Republic, ${ }^{6}$ Biomedical Centre, Faculty of Medicine in Pilsen, Charles University, Pilsen, Czech Republic, ${ }^{7}$ Department of Cybernetics, Faculty of Applied Sciences, University of West Bohemia in Pilsen, Pilsen, Czech Republic

Received December 18, 2015

Accepted December 22, 2016

On-line April 12, 2017

\section{Summary}

Emerging evidence indicates that polychlorinated biphenyls (PCBs) are involved in the development of diabetes mellitus in the obese. The purpose of this study was to determine mechanisms by which PCB $153\left(2,2^{\prime}, 4,4^{\prime}, 5,5^{\prime}\right.$-hexachlorobiphenyl) could influence diet-induced obesity and insulin resistance during adipogenesis. Lineage of h-ADMSCs was differentiated either as control (differentiation medium only), or with lipid vehicle modeling high fat nutrition (NuTRIflex) or lipid free vehicle (dimethylsulfoxide) for 28 days with or without PCB 153 daily co-exposure (in three concentrations $0.1,1$, and $10 \mu \mathrm{M})$. Gene expression analyses were performed using RT-qPCR at days 4, 10, 21, 24, 28; protein levels Akt and phosphorylated Akt (Phospho-Akt) by Western blot at days 4, and 21. PCB 153 treatment of h-ADMSCs only in lipid vehicle was associated with down regulation of key master genes of adipogenesis: PPARY, SREBP-1, PPARGC1B, and PLIN2 during the whole process of differentiation; and with increased Akt and decreased Phospho-Akt protein level at day 21. We have shown that PCB 153, in concentration $0.1 \mu \mathrm{M}$, has a potential in lipid rich environment to modulate differentiation of adipocytes. Because European and U.S. adults have been exposed to
PCB 153, this particular nutrient-toxicant interaction potentially impacts human obesity and insulin sensitivity.

\section{Key words}

Adipogenesis • PCBs • Gene expression • Phospho-Akt/Akt

\section{Corresponding author}

D. Mullerova, Department of Public Health and Preventive Medicine, Faculty of Medicine in Pilsen, Lidická 4, Pilsen, 301 66, Czech Republic. E-mail: dana.mullerova@lfp.cuni.cz

\section{Introduction}

Obesity is a rapidly growing pandemic. Visceral obesity is often seen in association with hypertension, dyslipidemia, insulin resistance and, type 2 diabetes mellitus (T2DM). T2DM is a complex condition resulting from the interaction between genetic and environmental factors, especially from unhealthy diets and decreased physical activity. However, emerging evidence from epidemiologic studies has also suggested the contribution of some environmental contaminants, including polychlorinated biphenyls (PCBs) to the observed 
growing T2DM (Lee et al. 2006), and the metabolic syndrome (Lee et al. 2007). PCBs are polyhalogenated aromatic hydrocarbons consisting of up to 10 chlorine atoms attached to a biphenyl group. A total of 1.3 million tons of PCBs consisting of 130 individual congeners were manufactured prior 1977 (Breivik et al. 2002) for use in electrical and other industrial applications. In the former Czechoslovakia, PCB were marketed as technical mixtures under the trade name "Delor" and were produced in the amount of about 21.500 tons in Eastern Slovakia from 1959 to 1984 , when the production was finally abolished (Pavuk et al. 2004). About 11.600 tons of this amount were used inside the former Czechoslovakia (Cerna et al. 2008). Unfortunately, thanks to this inheritance, the industrial areas of the Czech Republic have one of the highest PCB burdens of all Europe (Cerna et al. 2010). Although PCBs production and sale have been banned in many industrial countries for over 30 years, they are resistant to biodegradation and thus continue to be present in the diet however their exposure is continuously decreased. Contaminated food, especially fatty fish, meat and milk products, is still a main source of their exposure to general population.

Their concentration in human tissue is generally monitored by using examinations of human breast milk and also data from Europe showing their decreased concentration. 'Non-dioxin-like' PCB 153, 138, and 180 are the main congeners which show the highest concentration and are most frequently found in breast milk (Bencko et al. 1998). As well all of American adult NHANES participants had detectable circulating PCB levels in humans and PCB 153 has the highest median serum concentration of any single congeners (Cave et al. 2010).

Adipose tissue is a main storage site for many lipophilic persistent organic pollutants, including PCBs. Their structure determines their ability to interact with nuclear receptors, and thus they may modulate differentiation, metabolism, and secretory functions of adipose tissue (see review Mullerova and Kopecky 2007).

The effect of PCB 153, has not been adequately studied in models of adipocyte differentiation, likewise, in models with nutrient-toxicant interactions, which appear to be important in diet-induced obesity/metabolic syndrome (Hennig et al. 2007).

The purpose of this study is i) to determine, in a model of differentiating adipocytes, if PCB 153 chronic exposure itself is sufficient to alter expression of genes involved in adipocyte maturation; and ii) to determine if PCB 153 diluted in lipid vehicle simulating fatty diet worsens differentiation of adipocytes and their function by exacerbating previously implicated mechanisms such as insulin resistance.

\section{Materials and Methods}

In order to verify a hypothesis that PCB 153 may modify differentiation of adipocytes, and their function, expression of selected genes by RT real-time PCR and proteins by Western blot as markers of differentiation and insulin sensitivity were measured in a cell culture of human adipose derived mesenchymal stem cells (h-ADMSCs), which were differentiated either control (differentiation medium only, DM) or with lipid vehicle NuTRIflex (LV), or with dimethylsulfoxide vehicle (SV) for 28 days with or without PCB 153 daily co-exposure (in three concentrations $0.1 \mu \mathrm{M}, 1 \mu \mathrm{M}$, and $10 \mu \mathrm{M}$ ). Monitoring of gene expression was performed at days 4 , $10,21,24,28$ of differentiation.

\section{Cell culture differentiation and $P C B 153$ treatment}

$\mathrm{h}$-ADMSCs, isolated from a single female donor from subcutaneous adipose tissue and characterized by flow cytometry were obtained from the Invitrogen (Invitrogen Life Technologies GmbH, Darmstadt, Germany) and cultured in 6-well plate (TPP Techno Plastic Products, Switzerland) in commercially available culture medium MesenPRO RSTM Medium supplemented with MesenPRO RSTM Growth Supplement with reduced serum level (2\%), 1\% L-glutamine and $1 \%$ Gentamicine (all Invitrogen Life Technologies GmbH, Darmstadt, Germany).

For adipogenic differentiation, h-ADMSCs were seeded with a total number of $1 \times 105$ cells in a 6-well cell culture plate and cultured according to the manufacturer's instructions in StemPro ${ }^{\circledR}$ Adipogenesis Differentiation medium supplemented with $1 \%$ Gentamicine. The medium was changed every 3 days up to a total incubation time of 28 days.

The cells were maintained and cultured into differentiated adipocytes under $5 \% \mathrm{CO}_{2}$ atmosphere at $37^{\circ} \mathrm{C}$. Cells were incubated either control DM, containing insulin $1250 \mathrm{IU} / 1$ (glucose $23 \mathrm{mM}$, cholesterol $0.37 \mathrm{mM}$, triacylglyceroles (TG) $0.08 \mathrm{mM}$ ), or DM with $\mathrm{SV}$ or DM with LV (high fat medium, imitative high fat diet, NuTRIflex ${ }^{\circledR}$ Lipid peri: glucose $23 \mathrm{mM}$, cholesterol $0.35 \mathrm{mM}$, TG $1.069 \mathrm{mM}$ ). 
PCB 153 (Sigma Aldrich, St. Louis, MO, USA), was administered either in LV or in SV at three different concentrations $(0.1 \mu \mathrm{M}, 1 \mu \mathrm{M}$, and $10 \mu \mathrm{M})$ vs. controls $(\mathrm{DM}, \mathrm{DM}+\mathrm{LV}, \mathrm{DM}+\mathrm{SV})$. A gene expression analyses were performed at days 4, 10, 21, 24 and 28. Thus nine different treatment groups were evaluated in this fashion: $\mathrm{DM}, \quad \mathrm{DM}+\mathrm{LV}, \quad \mathrm{DM}+\mathrm{SV}, \quad \mathrm{DM}+\mathrm{LV}+\mathrm{PCB} 153-0.1 \mu \mathrm{M}$, DM+LV+PCB 153-1 $\mu \mathrm{M}, \quad$ DM+LV+PCB 153-10 $\mu \mathrm{M}$, $\mathrm{DM}+\mathrm{SV}+\mathrm{PCB} 153-0.1 \mu \mathrm{M}, \quad \mathrm{DM}+\mathrm{SV}+\mathrm{PCB} 153-1 \mu \mathrm{M}$, $\mathrm{DM}+\mathrm{SV}+\mathrm{PCB}$ 153-10 $\mu \mathrm{M}$.

\section{Real time-PCR}

Total RNA was isolated from a pellet of cells (approximately $10^{6}$ cells) by FastRNAPro Green Kit (QBIOgene, Irvine, CA, USA). Reverse transcription (RT) was performed from $250 \mathrm{ng}$ of total RNA with Superscript III Reverse Transcriptase (Life Technologies, Carlsbad, CA, USA) and random hexamers as primers.

Table 1 shows the sequences of primers and corresponding UPL probes generated by ProbeFinder Software (Roche, Mannheim, Germany). The primers were synthesized by East Port Praha (Prague, Czech Republic). A quantitative estimation was performed in technical duplicates using UPL probes (Table 1) on Stratagene Mx3005P apparatus (Agilent Technologies, Inc., Santa Clara, CA, USA). All samples were also assessed for the expression of reference genes GUSB, HPRT, YWHAZ. Selection of the most suitable reference genes was done prior to the study (unpublished data). The results are presented as normalized values $\left(2^{-\Delta \Delta \mathrm{Ct}}\right.$ algorithm) using geometric mean of quantification (Ct) of three reference genes (GUSB, HPRT, YWHAZ) (Kozera and Rapacz 2013).

\section{Determination of Phospho-Akt/Akt by Western blot}

On days 4 and 21, cells were lysed with M-PER Mammalian Protein Extraction Reagent (Thermo Fisher Scientific, Waltham, MA, USA) containing protease inhibitor cocktail (cOmplete Protease Inhibitor Cocktail Tablets, Roche, Basel, Switzerland) and phosphatase inhibitor cocktail (PhosSTOP Phosphatase Inhibitor Cocktail Tablets, Roche, Basel, Switzerland). The protein was quantified using Pierce ${ }^{\mathrm{TM}}$ BCA Protein Assay Kit (Thermo Fisher Scientific, Waltham, MA, USA) and $3 \mu \mathrm{g}$ aliquots of protein were electrophoresed by SDS-PAGE and transferred to Immun-Blot PVDF membranes (BioRad, Hercules, CA, USA).

Protein levels of Akt and Phospho-Akt were determined by PhosphoPlus Akt (Ser473) Antibody Duet kit (Cell Signaling Technologies, Danvers, MA, USA) containing primary antibodies Phospho-Akt (Ser473) (D9E) XP® Rabbit mAb (used in 1:2000 dilution) and AktT (pan) (C67E7) Rabbit mAb (used in 1:1000 dilution). Anti-rabbit IgG, HRP-linked Antibody (1:1000 dilution; Cell Signaling Technologies, Danvers, MA, USA) was used as a secondary antibody. For an internal control and purpose of relative quantification, glyceraldehyde 3-phosphate dehydrogenase (GAPDH) was detected by GAPDH (14C10) Rabbit mAb (1:2000 dilution; Cell Signaling Technologies, Danvers, MA, USA).

Immune complexes were visualized using WesternBright ECL HRP substrate (Advansta, Menlo Park, CA, USA) and the luminescent signal was detected and relative band intensity was analyzed with a digital documentation system and software Alliance 4.7 (UVItec, Cambridge, UK).

\section{Statistical analysis}

Statistical analyses were performed using Matlab Statistics Tool Box version R2012a for Windows. Non-parametric Wilcoxon two-sided signed-rank test was performed for statistical analysis. P-value less than 0.05 was considered statistically significant.

Also non-parametric Friedman's test was performed for statistical analyses of genes expression during the monitored days of differentiation between by PCB 153 exposed cells and controls. Friedman's test was calculated to assess whether there was a significant effect of the particular concentrations of PCB 153 on the temporal changes in gene expression.

\section{Results}

PCB 153 treatment altered mRNA expression of genes involved in differentiation of adipocytes cultured in $L V$, but had no effect on adipocytes cultured in $S V$ in comparison to a control with DM only

Gene expression was assessed in h-ADMSCs during the process of differentiation to analyze potential changes in expression of selected genes keeping cells in pluripotent state - OCT4 (octamer-binding transcription factor 4), NANOG (nanog homeobox). PCB 153 treatment altered these gene expressions only in differentiating adipocytes cultivated in $\mathrm{LV}+\mathrm{DM}$, where NANOG gene expression in LV+DM+PCB 153 (0.1 and $1 \mu \mathrm{M})$ was significantly decreased vs. both $\mathrm{LV}+\mathrm{DM}$ or $\mathrm{DM}(\mathrm{p}<0.05)$, but had no effect in SV+DM. OCT4 gene 
expression was altered by PCB 153 depending on concentration, while $0.1 \mu \mathrm{M}$ reduced, and $1 \mu \mathrm{M}$ increased OCT4 expression $(\mathrm{p}<0.05)$. There was no statistical difference between DM and PCB treated cell cultures in expression of SOX2.

PCB 153 exposure altered gene expression of $m R N A$ of proteins involved in lipid storage in ongoing process of differentiation

PLIN 2 (perilipin 2) expression was decreased in $\mathrm{LV}+\mathrm{DM}+\mathrm{PCB} 153 \quad(0.1 \mu \mathrm{M})$ vs. $\mathrm{LV}+\mathrm{DM} \quad(\mathrm{p}<0.05)$. Although there was a non-significant trend towards higher PLIN 2 expression in LV vs. DM $(p=0.13)$ we have seen the similar pattern in dichlorodiphenyl dichloroethylene (DDE) exposure (Mullerova et al. 2016), where LV+DM increased expression of PLIN 2 vs. DM, and this increase was stifled by DDE exposure (Mullerova et al. 2016). No alterations were seen in PCB 153 co-exposure in SV+DM.

PCB 153 exposure down-regulated gene expression of main regulators of adipogenesis PPAR, SREBP-1, and PPARGC1B

PPAR $\gamma$ (peroxisome proliferator-activated receptor $\gamma$ ) is a member of the nuclear receptor superfamily of ligand activated transcription factors. It is highly expressed in adipose tissue and it seems to be a main regulator of adipogenesis (Ni et al. 2013). PPAR $\gamma$ expression was in comparison to DM significantly decreased in $\mathrm{LV}+\mathrm{DM}$ and in $\mathrm{LV}+\mathrm{DM}+\mathrm{PCB} 153$ in concentrations $10 \mu \mathrm{M}$ and $0.1 \mu \mathrm{M}$ vs. $\mathrm{DM} \quad(\mathrm{p}<0.05)$, moreover there was a significant difference between $\mathrm{LV}+\mathrm{DM}$ and $\mathrm{LV}+\mathrm{DM}+\mathrm{PCB} 153$ in concentration $0.1 \mu \mathrm{M}$, where this concentration further intensified reduction of PPAR $\gamma$ gene expression (Fig. 1).

SREBP-1 (sterol regulatory element-binding protein-1) is also involved in adipogenesis. PCB 153 in concentrations 0.1 and $1 \mu \mathrm{M}$ reduced gene expression of SREBP-1 in comparison to DM $(\mathrm{p}<0.05)$ or to $\mathrm{LV}+\mathrm{DM}$, however in case of concentration $0.1 \mu \mathrm{M}$ only at $\mathrm{p}$ value 0.07. There was a significant difference in SREBP-1 expression between LV+DM and DM ( $p<0.05$ ) (Fig. 1).

Expression of PPARGC1B (peroxisome proliferator-activated receptor $\gamma$ coactivator 1 $\beta$ ) mRNA which is induced during white and brown adipocyte differentiation, and regulates mitochondrial oxidative metabolism, was significantly decreased in $\mathrm{LV}+\mathrm{DM}+\mathrm{PCB} 153$ in concentrations 10 and $0.1 \mu \mathrm{M}$ vs. DM $(p<0.05)$ (Fig. 1). PPARGC1B mRNA is highly responsive to environmental cues and coordinate metabolic gene programs through interaction with transcription factors and chromatin-remodeling proteins.

$L V$, but not PCB 153 exposure altered gene expression of enzymes involved in adipocyte lipid metabolism

There were also evident alterations in gene expression of enzymes involved in fatty acids de novo synthesis (FASN, fatty acid synthase) and gene implicated in TG lipolysis by hormone-sensitive lipase (LIPE), under LV+DM treatment vs. DM, however without any additional effects of PCB 153 exposure. FASN and LIPE gene expressions were statistically significantly decreased in $\mathrm{LV}+\mathrm{DM}$ and $\mathrm{LV}+\mathrm{DM}+$ PCB 153 in all examined concentrations $(0.1 \mu \mathrm{M}, 1 \mu \mathrm{M}$, and $10 \mu \mathrm{M}$ ), in comparison to $\mathrm{DM}$, however there was not a statistical difference between $\mathrm{LV}+\mathrm{DM}$ and $\mathrm{LV}+\mathrm{DM}+\mathrm{PCB}$ exposed cultures. Transcription of FASN gene can be activated by stimulatory factors acting through SREBP-1.

PCB 153 exposure altered gene expression of proteins involved in adipocyte glucose metabolism and insulin sensitivity

No significant differences were seen in INSR (insulin receptor) or in AKT2 (protein kinase B) genes expression, apart from a statistical difference between $\mathrm{LV}+\mathrm{DM}+\mathrm{PCB} 153$, in $0.1 \mu \mathrm{M}$ vs. $\mathrm{LV}+\mathrm{DM}$ where the expression is significantly lower $(\mathrm{p}<0.05)$.

There were not found any differences in expression of ACLY (ATP citrate lyase) gene after exposure of $\mathrm{PCB} 153$ in comparison to $\mathrm{DM}$ or $\mathrm{DM}+\mathrm{LV}$ or $\mathrm{DM}+\mathrm{SV}$.

PCB 153 altered Phospho-Akt levels and PhosphoAkt/Akt measured by Western blot although the effect is opposite at day 4 and 21 of ongoing differentiation

Although Akt gene expression in $\mathrm{LV}+\mathrm{DM}$, and much more in all three PCB 153 concentrations, especially in $0.1 \mu \mathrm{M}$ and $1 \mu \mathrm{M}$ co-exposed cultures, was reduced in comparison to DM on day 4 of differentiation, Phospho-Akt levels were doubled in LV+DM and in all these co-exposed cultures in comparison to DM. However, on day 21 it was completely vice versa. Relation of Phospho-Akt to Akt was higher on day 4, and lower on day 21 in $\mathrm{LV}+\mathrm{DM}$, and more profound PCB in PCB 153 co-exposed cultures than DM, once again especially in concentrations 0.1 and $1 \mu \mathrm{M}$ (Fig. 2). 


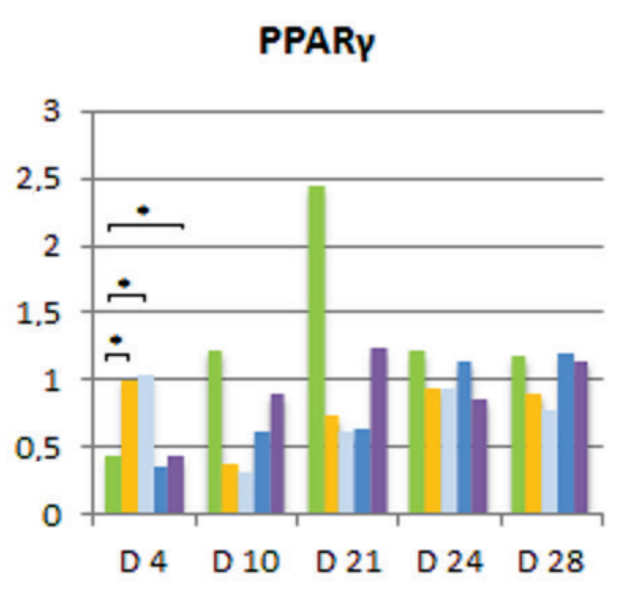

PPARGC1B

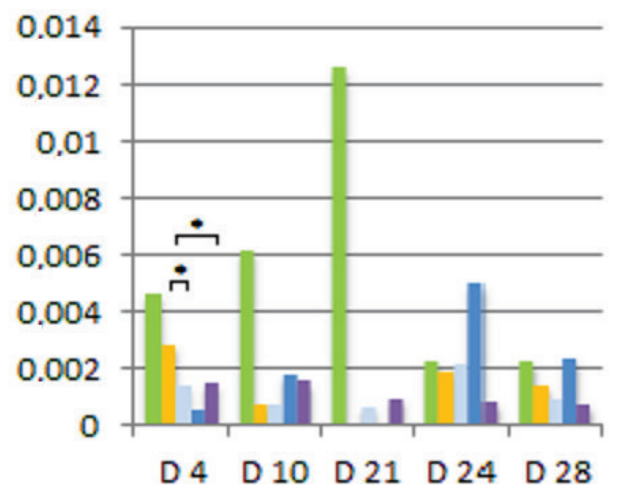

SREBP1

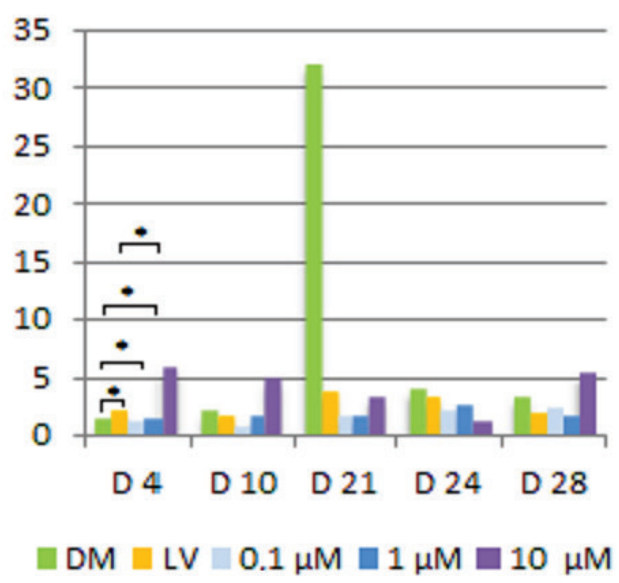

Fig. 1. $P C B 153$ chronic co-exposure down-regulates PPARy, PPARGC1B, SREBP-1 gene expression. DM - differentiation medium, LV - differentiation medium with lipid vehicle, $0.1 \mu \mathrm{M}-$ differentiation medium with lipid vehicle with PCB 153 concentration $0.1 \mu \mathrm{M}, 1 \mu \mathrm{M}$ - differentiation medium with lipid vehicle with PCB 153 concentration $1 \mu \mathrm{M}, 10 \mu \mathrm{M}$ - differentiation medium with lipid vehicle with PCB 153 concentration $10 \mu \mathrm{M}$, D4, D10, D21, D24, D28 - days 4, 10, 21, 24, 28.

PPAR Y $(p<0.05)$ in: DM vs. LV+DM; DM vs. LV+DM+PCB 153 $(10 \mu \mathrm{M}$ and $0.1 \mu \mathrm{M})$; LV+DM vs. LV+DM+PCB $153(0.1 \mu \mathrm{M})$. PPARGC1B $(\mathrm{p}<0.05)$ in: DM vs. LV+DM+PCB $153(0.1 \mu \mathrm{M}$ and $10 \mu \mathrm{M})$.

SREBP-1 $(p<0.05)$ in: DM vs. LV+DM; DM vs. LV+DM+PCB 153 $(0.1 \mu \mathrm{M}$ and $1 \mu \mathrm{M}) ; \mathrm{DM}+\mathrm{LV}$ vs. LV+DM+PCB $153(1 \mu \mathrm{M}) . \mathrm{p}=0.07$ in: $D M+L V$ vs. $L V+D M+P C B ~ 153(0.1 \mu M)$.

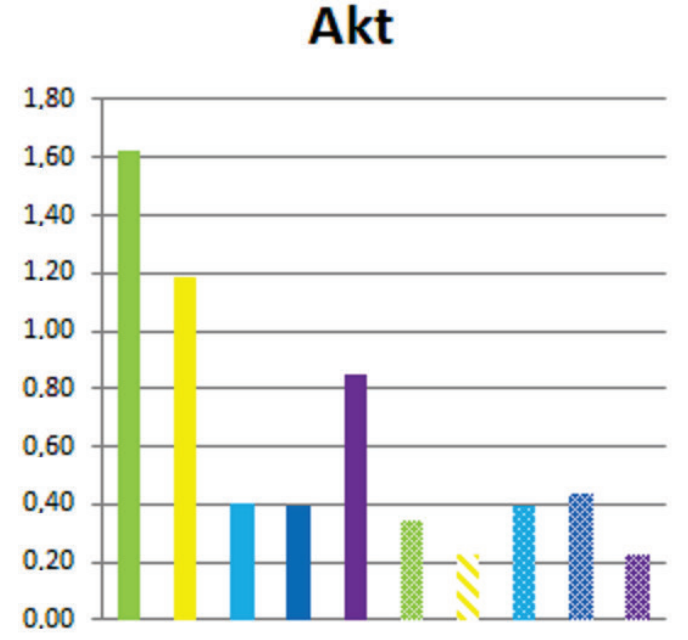

pAkt

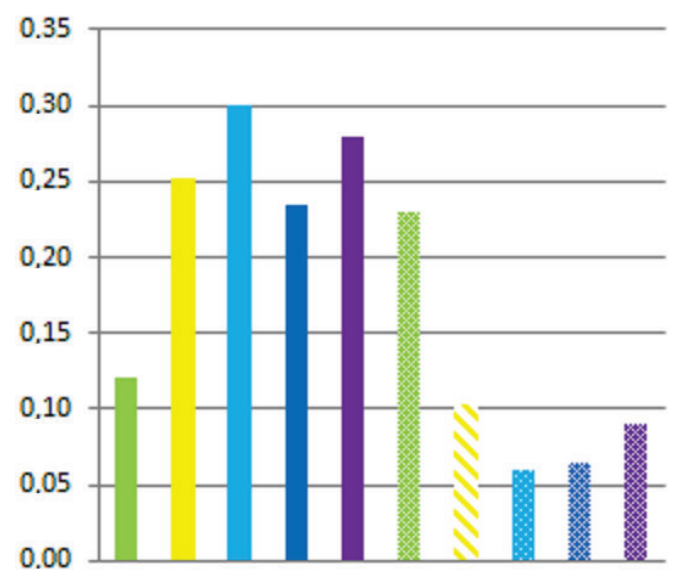

pAkt/Akt

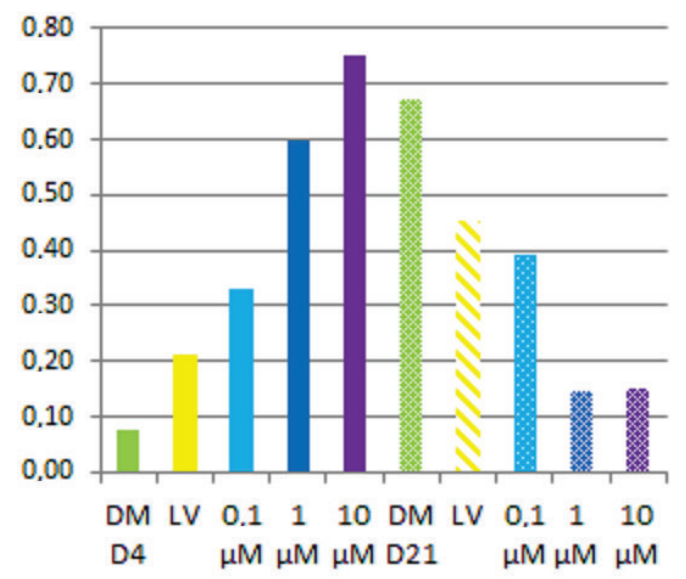

Fig. 2. $P C B 153$ chronic co-exposure alters Phospho-Akt levels and Phospho-Akt/Akt measured by Western blot. DM differentiation medium, LV - differentiation medium with lipid vehicle, $0.1 \mu \mathrm{M}$ - differentiation medium with lipid vehicle with PCB 153 concentration $0.1 \mu \mathrm{M}, 1 \mu \mathrm{M}$ - differentiation medium with lipid vehicle with PCB 153 concentration $1 \mu \mathrm{M}, 10 \mu \mathrm{M}-$ differentiation medium with lipid vehicle with PCB 153 concentration $10 \mu \mathrm{M}, \mathrm{D} 4$ - day 4, D21 - day 21 . 


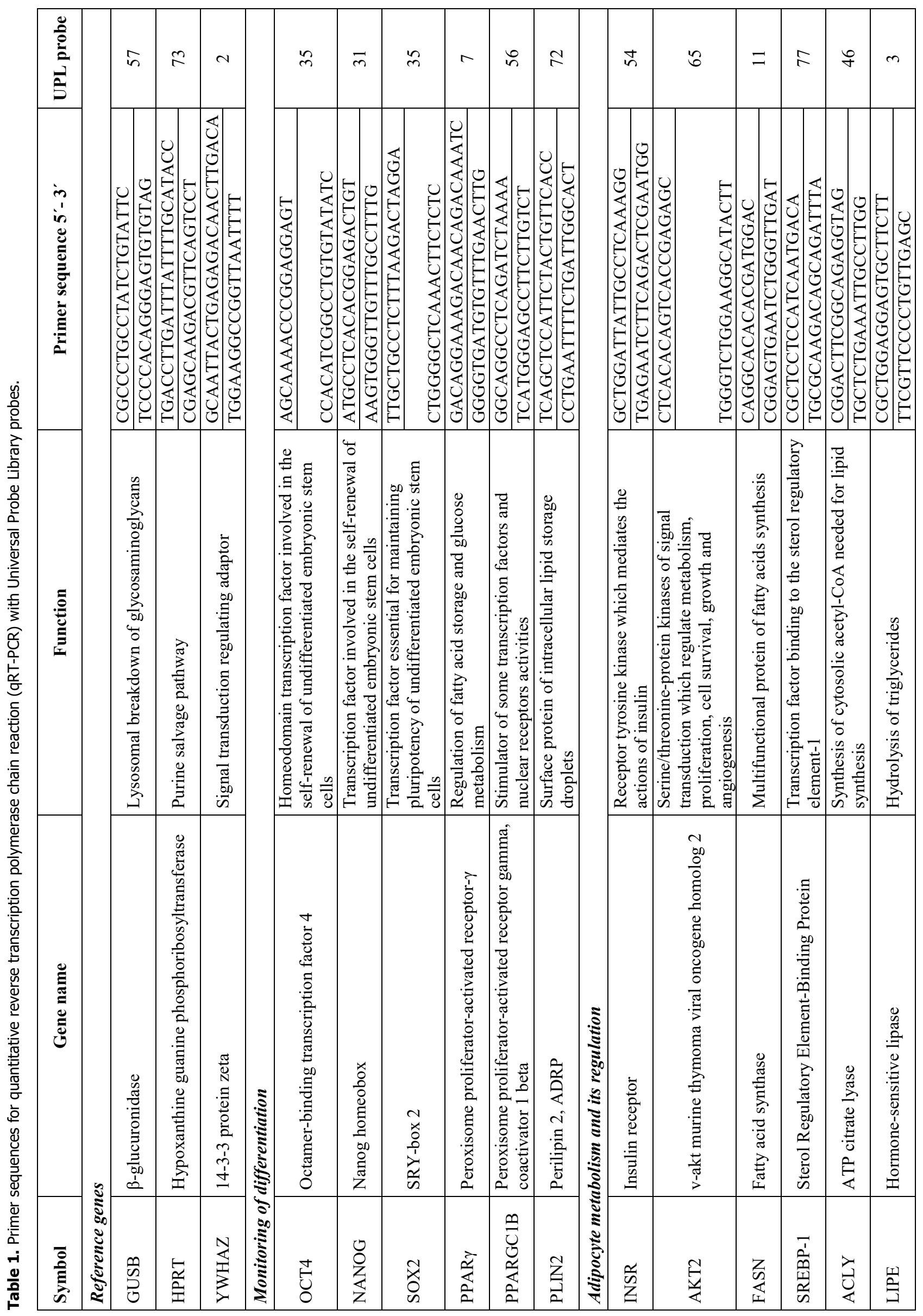




\section{Discussion}

PCBs are known to concentrate within adipose tissue. Our aim was to evaluate effects of chronic exposure of h-ADMSCs to PCB 153 during the ongoing process of differentiation.

Chronic toxicity in this study was monitored by morphology, differentiation potential towards adipogenic lineage, and especially by expression analysis of 13 genes, taking part in differentiation and as well in functions of maturated adipocytes, and the level of active Akt protein (Phospho-Akt).

PCB 153 levels were similar to those found in human lipid adjusted serum 10-1260 ng/g (Mullerova et al. 2015). Therefore, the PCB 153 dose in our study reflected the serum levels observed in obese human populations.

Adipogenesis and lipogenesis are governed by a vast number of enzymes that act together along with key hormones and metabolites to regulate fat cell metabolism. Differentiation of h-ADMSCs, adipocyte precursors, is driven by a cascade of events controlled by transcription regulators, coactivators, and cell-cycle controls. This entire process is closely regulated at the transcriptional level.

h-ADMSCs were induced to differentiate in vitro by means of DM containing an external cue, such as insulin, glucocorticoids and/or molecules that can increase intracellular cAMP. These cues trigger the beginning of a transcriptional cascade composed of a network of proteins that mediate the functions of adipocytes.

We did not observe any effect of PCB 153 on adipogenesis in the absence of high fat vehiculum/feeding, however, there were alterations of gene expressions in case of fat vehiculum with PCB 153. Similarly Wahlang et al. (2013) documented that PCB 153 is a relevant "second hit" mechanism in the genesis and progression of obesity occurring in the context of a high fat diet. In consistency with findings of a meta-analysis within 12 European Birth Cohorts, where a low-level exposure to PCB was inversely associated with fetal growth (Govarts et al. 2012), in our study the concentration of PCB 153 at lower concentration $0.1 \mu \mathrm{M}$ and $1 \mu \mathrm{M}$, had the more profound effect on adipogenesis in comparison to the highest tested concentration $10 \mu \mathrm{M}$. Similarly a non-linear pattern between persistent organic pollutants exposure and serum lipids/obesity has been shown (Arrebola et al. 2014).
At the beginning of differentiation h-ADMSCs expressed pluripotency genes OCT4, SOX2, NANOG. They are down-regulated with the ongoing process of differentiation. We observed faster down-regulation of NANOG as effects of PCB 153, in concentration $0.1 \mu \mathrm{M}$, diluted in fat vehicle. It may be a stimulus to differentiation to adipocyte and loss of pluripotency of mesenchymal stem cells under PCB 153 treatment.

FASN is highly expressed in lipogenic tissues such as adipose tissue, liver, lactating breast. It is a key enzyme in the de novo synthesis of long-chain fatty acids starting with acetyl coenzyme A and malonylcoenzyme A using NADPH as a reducing factor. The observed lower levels of FASN expression in our study are determined because cells obtained their needed fatty acids from fat vehiculum, rather than from lipogenesis, as occurs in normal cells. FASN provides saturated lipids for membrane synthesis, increased saturated lipid content in the membranes. FASN expression and activities are up-regulated by androgens and epidermal growth factor. However, we were not able to show any additional effects to fat vehiculum, although PCB 153 shows a weak antiandrogenic effect. FASN has been implicated in diabetes and cancer development. It also can be overexpressed through an activation of the PI3K/Akt pathway.

LIPE catalyzes both the release of fatty acids from storage triglycerides in adipocytes and the liberation of cholesterol from cholesterol esters in steroidogenic tissues. LIPE activity is regulated in a tissue-, development- and hormone-specific fashion, the latter in large part by serine phosphorylation (Sztrolovics et al. 1997). Similarly to FASN, there was a down-regulation of LIPE after the treatment of fat vehiculum or fat vehiculum with PCB 153, with no differences between them.

PPAR $\gamma$, a member of the nuclear receptor superfamily of ligand activated transcription factors, represents one of the key regulatory elements taking part in proliferation of precursor's cells and their differentiation into mature adipocytes. Its activation by various ligands (such as fatty acids and eicosanoids) sets in the run the transcription process promoting adipocyte differentiation. The level of PPAR $\gamma$ protein peaks soon after differentiation and remains high in mature adipocytes. Thus PPAR $\gamma$ functions as a cellular sensor for nutritional fatty acids which, in mature adipocytes, is capable of transducing metabolic signals into the transcriptional control of genes involved in insulin 
signaling, glucose and fatty acids metabolism. In response to energy overfeeding, the expression of PPAR $\gamma$ rather than SREBP1 was closely associated with most adipogenic or lipogenic genes (Ji et al. 2014). In our study PPAR $\gamma$ expression was significantly down-regulated in lipid vehicle and still more after exposure to PCB 153 in concentration $0.1 \mu \mathrm{M}$. Consistent with our results de novo lipogenesis pathway has been demonstrated to be repressed in obese, insulin-resistant adipose tissue of both humans and rodens however with cytokine-mediated suppression of PPAR $\gamma$ and SREBP1 (Zhang et al. 1996, Sewter et al. 2002, Tang et al. 2006, Ye 2008, Guilherme et al. 2009, Keuper et al. 2013). $\operatorname{PPAR} \gamma$ is required for activation of the lipolytic regulatory network, dysregulation of which is an important feature of obesity-induced insulin resistance in humans. Defective PPAR $\gamma$ impairs catecholamineinduced lipolysis. This abnormal lipolytic response is exacerbated by a state of positive energy balance in leptin-deficient ob/ob mice (Rodriguez-Cuenca et al. 2012). Defective PPAR $\gamma$ is associated with decreased basal expression of the lipase genes PNPLAZ (ATGL) and LIPE (HSL), and lipid droplet protein genes FSP27 and PLIN 2 in vivo and in vitro. Only few studies based on preadipocytes model have shown that PCBs, especially dioxin like PCBs as PCB 126 have potential by the way of AhR activation to inhibit PPAR $\gamma$ transcription and subsequent adipogenesis (Gadupudi et al. 2015).

MiRNA and its host gene PPARGC1B are primary PPAR $\gamma$ targets in adipocytes (John et al. 2012). MiRNA can induce lipogenesis and expression of lipogenic genes, when overexpressed during adipogenesis of mesenchymal precursors (Takada et al. 2009). PPARGC1B is a known transcriptional co-activator responsible for inducing the target genes of numerous transcription factors that are involved in regulation of lipogenesis and related processes (Lin et al. 2005, Ortega et al. 2010).

The Akt (protein kinase B) pathway is a signal transduction pathway that promotes the survival and growth in response to extracellular signals. Activatedphosphorylated Akt mediates downstream responses, including cell survival, growth, proliferation, cell migration and angiogenesis, by phosphorylating a range of intracellular proteins.

The pathway is highly regulated by multiple mechanisms, often involving cross-talk with other signaling pathways. Problems with PI3K-Akt pathway regulation have been linked to a range of diseases such as cancer and T2DM. Akt phosphorylates as many as 100 different substrates, leading to a wide range of effects on the cell. For example increased insulin signaling at Akt signaling node may lead to reduced insulin sensitivity at endothelial nitric oxide synthase (eNOS) signaling code (Kearney 2013). The extremes of insulin sensitivity both impact unfavourably on endothelian cell function. Our study showed an increased Akt level and decreased Phospho-Akt level, measured by Western blot, at day 21 of ongoing process of differentiation because of added lipid vehicle; however these changes were more profound after PCB 153 co-exposure, especially in $0.1 \mu \mathrm{M}$ and $1 \mu \mathrm{M}$ concentrations. Due to that fact the relation of Phospho-Akt to Akt was reduced once again especially in concentrations 0.1 and $1 \mu \mathrm{M}$.

In conclusion, this study gives us a molecular insight of PCB 153 induced changes in gene expression with a special reference to differentiation process in the h-ADMSCs line which leads to the mature adipocytes. These changes are visible only in fat (nutrient toxic) environment and are associated especially with down-regulation of key master genes of adipogenesis and pAkt level. Dysfunctional adipocytes play a significant role in initiating insulin resistance. Preadipocytes make up a large portion of adipose tissue and are necessary for the generation of functional mature adipocytes through adipogenesis.

\section{Conflict of Interest}

There is no conflict of interest.

\section{Acknowledgements}

This research was supported by the NT 14330-3/2013 Polychlorinated persistent organic pollutants in the ethiopathogenesis of obesity and insulin resistance and by the Charles University Research Fund (project number Q39).

\section{Abbreviations}

ACLY - ATP citrate lyase, Akt - protein kinase B, DDE - dichlorodiphenyl dichloroethylene, eNOS endothelial nitric oxide synthase, FASN - fatty acid synthase de novo, h-ADMSCs - human adipose-derived mesenchymal stem cells, LV - lipid vehicle (NuTRIflex), miRNA - micro-ribonucleic acid, NADPH nicotinamide adenine dinucleotide phosphate, NANOG nanog homeobox, NHANES - National Health and Nutrition Examination Survey, INSR - insulin receptor, LIPE - hormone-sensitive lipase, OCT - octamer-binding 
transcription factor 4, pAkt - phosphorylated Akt, PCBs - polychlorinated biphenyls, PCR - polymerase chain reaction, $\mathrm{PI} 3 \mathrm{~K} / \mathrm{AKT}$ - phosphatidylinositol 3-kinase/AKT pathway, PLIN2 - perilipin 2, PPAR $\gamma$ peroxisome proliferator-activated, receptor gamma,
PPARGC1B - peroxisome proliferator-activated receptor $\gamma$ coactivator $1 \beta$, SOX2 - SRY-box 2, SREBP-1 - sterol regulatory element-binding protein-1, $\mathrm{SV}$ - lipid free vehicle- dimethylsulfoxid, T2DM - type 2 diabetes mellitus.

\section{References}

ARREBOLA JP, OCANA-RIOLA R, ARREBOLA-MORENO AL, FERNANDEZ-RODRIGUEZ M, MARTINOLMEDO P, FERNANDEZ MF, OLEA N: Associations of accumulated exposure to persistent organic pollutants with serum lipids and obesity in an adult cohort from Southern Spain. Environ Pollut 195: 9-15, 2014.

BENCKO V, SKULOVA Z, KRECMEROVA M, LIEM AK: Selected polyhalogenated hydrocarbons in breast milk. Toxicol Lett 96-97: 341-345, 1998.

BREIVIK K, SWEETMAN A, PACYNA JM, JONES KC: Towards a global historical emission inventory for selected PCB congeners - a mass balance approach. 1. Global production and consumption. Sci Total Environ 290: 181-198, 2002.

CAVE M, APPANA S, PATEL M, FALKNER KC, MCCLAIN CJ, BROCK G: Polychlorinated biphenyls, lead, and mercury are associated with liver disease in American adults: NHANES 2003-2004. Environ Health Perspect 118: 1735-1742, 2010.

CERNA M, MALY M, GRABIC R, BATARIOVA A, SMID J, BENES B: Serum concentrations of indicator PCB congeners in the Czech adult population. Chemosphere 72: 1124-1131, 2008.

CERNA M, BENCKO V, BRABEC M, SMID J, KRSKOVA A, JECH L: Exposure assessment of breast-fed infants in the Czech Republic to indicator PCBs and selected chlorinated pesticides: area-related differences. Chemosphere 78: $160-168,2010$.

GADUPUDI G, GOURRONC FA, LUDEWIG G, ROBERTSON LW, KLINGELHUTZ AJ: PCB126 inhibits adipogenesis of human preadipocytes. Toxicol In Vitro 29: 132-141, 2015.

GOVARTS E, NIEUWENHUIJSEN M, SCHOETERS G, BALLESTER F, BLOEMEN K, DE BOER M, CHEVRIER C, EGGESBO M, GUXENS M, KRAMER U, LEGLER J, MARTINEZ D, PALKOVICOVA L, PATELAROU E, RANFT U, RAUTIO A, PETERSEN MS, SLAMA R, STIGUM H, TOFT G, TRNOVEC T, VANDENTORREN S, WEIHE P, KUPERUS NW, WILHELM M, WITTSIEPE J, BONDE JP: Birth weight and prenatal exposure to polychlorinated biphenyls (PCBs) and dichlorodiphenyldichloroethylene (DDE): a metaanalysis within 12 European Birth Cohorts. Environ Health Perspect 120: 162-170, 2012.

GUILHERME A, TESZ GJ, GUNTUR KV, CZECH MP: Tumor necrosis factor-alpha induces caspase-mediated cleavage of peroxisome proliferator-activated receptor gamma in adipocytes. $J$ Biol Chem 284: 17082-17091, 2009.

HENNIG B, ETTINGER AS, JANDACEK RJ, KOO S, MCCLAIN C, SEIFRIED H, SILVERSTONE A, WATKINS B, SUK WA: Using nutrition for intervention and prevention against environmental chemical toxicity and associated diseases. Environ Health Perspect 115: 493-495, 2007.

JI P, DRACKLEY JK, KHAN MJ, LOOR JJ: Overfeeding energy upregulates peroxisome proliferator-activated receptor (PPAR)gamma-controlled adipogenic and lipolytic gene networks but does not affect proinflammatory markers in visceral and subcutaneous adipose depots of Holstein cows. J Dairy Sci 97: 3431-3440, 2014.

JOHN E, WIENECKE-BALDACCHINO A, LIIVRAND M, HEINANIEMI M, CARLBERG C, SINKKONEN L: Dataset integration identifies transcriptional regulation of microRNA genes by PPARgamma in differentiating mouse 3T3-L1 adipocytes. Nucleic Acids Res 40: 4446-4460, 2012.

KEARNEY MT: Changing the way we think about endothelial cell insulin sensitivity, nitric oxide, and the pathophysiology of type 2 diabetes: the FoxO is loose. Diabetes 62: 1386-1388, 2013.

KEUPER M, WERNSTEDT ASTERHOLM I, SCHERER PE, WESTHOFF MA, MOLLER P, DEBATIN KM, STRAUSS G, WABITSCH M, FISCHER-POSOVSZKY P: TRAIL (TNF-related apoptosis-inducing ligand) regulates adipocyte metabolism by caspase-mediated cleavage of PPARgamma. Cell Death Dis 4: e474, 2013.

KOZERA B, RAPACZ M: Reference genes in real-time PCR. J Appl Genet 54: 391-406, 2013. 
LEE DH, LEE IK, SONG K, STEFFES M, TOSCANO W, BAKER BA, JACOBS DR JR: A strong dose-response relation between serum concentrations of persistent organic pollutants and diabetes: results from the National Health and Examination Survey 1999-2002. Diabetes Care 29: 1638-1644, 2006.

LEE DH, LEE IK, PORTA M, STEFFES M, JACOBS DR JR: Relationship between serum concentrations of persistent organic pollutants and the prevalence of metabolic syndrome among non-diabetic adults: results from the National Health and Nutrition Examination Survey 1999-2002. Diabetologia 50: 1841-1851, 2007.

LIN J, HANDSCHIN C, SPIEGELMAN BM: Metabolic control through the PGC-1 family of transcription coactivators. Cell Metab 1: 361-370, 2005.

MULLEROVA D, KOPECKY J: White adipose tissue: storage and effector site for environmental pollutants. Physiol Res 56: 375-381, 2007.

MULLEROVA DM, MATEJKOVA D, DVORAKOVA J, MULLER L, ROSMUS J: Persistent organochlorine pollutants in obese women after diet induced weight loss: five years follow up study. Centr Eur J Public Health 23: 214-217, 2015.

MULlEROVA D, PESTA M, CEDIKOVA M, DVORAKOVA J, KULDA V, SRBECKA K, MULLER L, DVORAK P, KRIPNEROVA M, KRALICKOVA M, BABUSKA V, KUNCOVA J: DDE downregulates PLIN2 expression during differentiation of mesenchymal stem cells into adipocytes in lipid-enriched medium. J Appl Biomed 14: 113-117, 2016.

NI Y, JI C, WANG B, QIU J, WANG J, GUO X: A Novel pro-adipogenesis factor abundant in adipose tissues and overexpressed in obesity acts upstream of PPARgamma and C/EBPalpha. J Bioenerg Biomembr 45: 219-228, 2013.

ORTEGA FJ, MORENO-NAVARRETE JM, PARDO G, SABATER M, HUMMEL M, FERRER A, RODRIGUEZHERMOSA JI, RUIZ B, RICART W, PERAL B, FERNANDEZ-REAL JM: MiRNA expression profile of human subcutaneous adipose and during adipocyte differentiation. PLoS One 5: e9022, 2010.

PAVUK M, CERHAN JR, LYNCH CF, SCHECTER A, PETRIK J, CHOVANCOVA J, KOCAN A: Environmental exposure to PCBs and cancer incidence in eastern Slovakia. Chemosphere 54: 1509-1520, 2004.

RODRIGUEZ-CUENCA S, CAROBBIO S, VELAGAPUDI VR, BARBARROJA N, MORENO-NAVARRETE JM, TINAHONES FJ, FERNANDEZ-REAL JM, ORESIC M, VIDAL-PUIG A: Peroxisome proliferator-activated receptor gamma-dependent regulation of lipolytic nodes and metabolic flexibility. Mol Cell Biol 32: 1555-1565, 2012.

SEWTER C, BERGER D, CONSIDINE RV, MEDINA G, ROCHFORD J, CIARALDI T, HENRY R, DOHM L, FLIER JS, O'RAHILLY S, VIDAL-PUIG AJ: Human obesity and type 2 diabetes are associated with alterations in SREBP1 isoform expression that are reproduced ex vivo by tumor necrosis factor-alpha. Diabetes 51: 1035-1041, 2002.

SZTROLOVICS R, WANG SP, LAPIERRE P, CHEN HS, ROBERT MF, MITCHELL GA: Hormone-sensitive lipase (Lipe): sequence analysis of the 129Sv mouse Lipe gene. Mamm Genome 8: 86-89, 1997.

TAKADA I, KOUZMENKO AP, KATO S: Molecular switching of osteoblastogenesis versus adipogenesis: implications for targeted therapies. Expert Opin Ther Targets 13: 593-603, 2009.

TANG X, GUILHERME A, CHAKLADAR A, POWELKA AM, KONDA S, VIRBASIUS JV, NICOLORO SM, STRAUBHAAR J, CZECH MP: An RNA interference-based screen identifies MAP4K4/NIK as a negative regulator of PPARgamma, adipogenesis, and insulin-responsive hexose transport. Proc Natl Acad Sci US A 103: 2087-2092, 2006.

WAHLANG B, BEIER JI, CLAIR HB, BELLIS-JONES HJ, FALKNER KC, MCCLAIN CJ, CAVE MC: Toxicantassociated steatohepatitis. Toxicol Pathol 41: 343-360, 2013.

YE J: Regulation of PPARgamma function by TNF-alpha. Biochem Biophys Res Commun 374: 405-408, 2008.

ZHANG B, BERGER J, HU E, SZALKOWSKI D, WHITE-CARRINGTON S, SPIEGELMAN BM, MOLLER DE: Negative regulation of peroxisome proliferator-activated receptor-gamma gene expression contributes to the antiadipogenic effects of tumor necrosis factor-alpha. Mol Endocrinol 10: 1457-1466, 1996. 